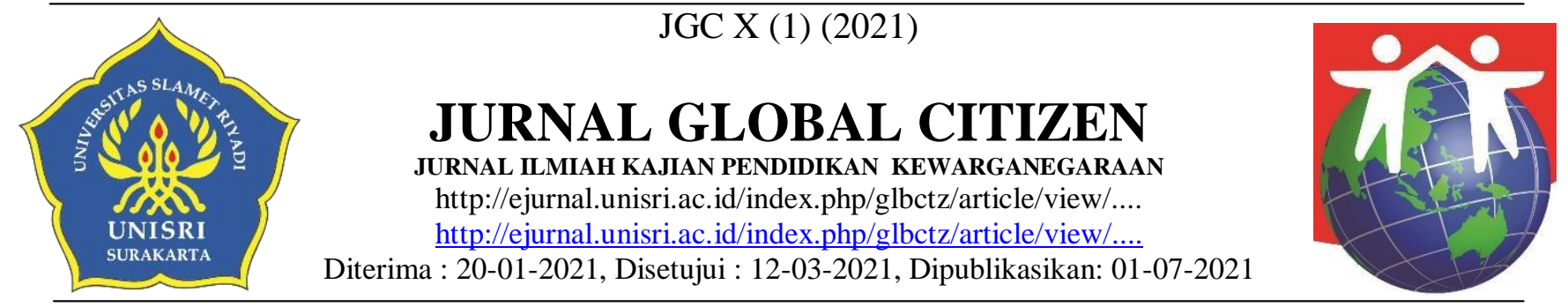

\title{
KEDUDUKAN LEMBAGA PERTAHANAN DALAM MENANGGULANGI PANDEMI COVID-19
}

\author{
Resa Agustina Perdana ${ }^{1)}$,Anita Trisiana ${ }^{2)}$,Latifatul Azizah ${ }^{3)}$ \\ Universitas Slamet Riyadi \\ rezavania23@gmail.com,latifatulazizah33@gmail.com
}

\begin{abstract}
ABSTRAK
Pada tahun 2020, Tanah Air Indonesia terkena virus ialah pandemic COVID-19 (coronavirus disease 2019). Keterkaitan lembaga pertahanan sangat penting untuk menghadapi keadaan yang berbahaya pada kesehatan global yang sudah muncul semejak awal Pandemi COVID-19 datang di Negara Indonesia, di awali dari pelaksanaan Pembatasan Sosial Berskala Besar (PSBB) sampai pada pelaksanaan new normal. Keterkaitan tersebut mengakibatkan terjadinya fakta dan opini. Beberapa pihak menanggapi sebagai sesuatu yang normal tetapi sebagian pihak lainnya mengkritik hal yang penting tentang keterkaitan lembaga pertahanan dan juga berpusat pada kedudukan kedua lembaga pertahanan yaitu Tentara Nasional Indonesia (TNI) dan Kementerian Pertahanan (Kemhan) untuk menanggulangi pandemi COVID-19. Metode yang di pergunakan yaitu dengan menggunakan data kualitatif. Orang yang meneliti juga menggunakan teori kedudukan serta rancangan pertahanan negara dalam penindakan pandemi COVID-19. Hasilnya menampilkan Tentara Nasional Indonesia (TNI) mempunyai kedudukan yang sangat penting diberbagai macam bidang yaitu bidang keamanan ,kesehatan ,serta sosial-ekonomi dalam upaya mengatasi pandemi COVID-19 yang ada di Indonesia. Kementerian Pertahanan juga berperan aktif baik dari dalam maupun dari luar.
\end{abstract}

Kata Kunci : kedudukan, mempertahanan negara, wabah corona 


\begin{abstract}
In the year 2020, the Indonesian homeland was affected by viruses called coroncovid-19 (coronavirus disease 2019). The links of defense agencies are critical to the dangerous state of global health that has emerged since the beginning of the covid-19 pandemic came to Indonesia, where they initiated from large-scale social restrictions (PSBB) to new normal implementation. That connection has resulted in facts and opinions. Some responded as normal but others criticized the link between defense agencies and also centered on the defense positions of the Indonesian national army (TNI) and the defense ministry (Kemhan) to cope with the covid-19 pandemic. The method is to use qualitative data. Research also employed the theory of position and defense plans of the state in eradicating the covid-19 pandemic. The result was that the Indonesian national army (tni) held a high value and wide range of security, health, and socioeconomic efforts to cope with the covid-19 pandemic in Indonesia. The ministry of defense played an active role both inside and outside.
\end{abstract}

Keywords: position, prisoner of state, plague of corona 


\section{PENDAHULUAN}

Pada awal Tahun 2020, Negara kita telah dihebohkan dengan adanya Coronavirus Disease (COVID-19) yang sudah mulai menyebar keseluruh wilayah Indonesia bahkan keseluruh dunia. COVID-19 muncul di Indonesia pada tanggal 2 Maret 2020. Virus ini menjadi salah satu wabah yang tersebar di berbagai belahan dunia. Semenjak saat itu,warga masyarakat lebih berhati-hati dalam melakukan aktivitas. Dalam perkembangannya tercatat yang positif COVID-19 telah mencapai 549.510 orang, pasien yang negatif mencapai 458.890 orang, dan yang meninggal dunia mencapai 17.200 orang. COVID-19 merupakan penyakit atau virus yang sangat berbahaya dan mematikan. Pandemi COVID-19 sudah menjadi krisis kesehatan global yang berakibat pada kesehatan warga masyarakat yang terdampak COVID-19, namun juga memicu terhadap berbagai macam bidang seperti bidang keamanan,kesehatan,dan sosial-ekonomi masyarakat. Akibat dari bidang sosialekonomi masyakarat banyak terjadinya PHK (Pemutusan Hubungan Kerja) di berbagai pabrik atau perusahaan karena gagal dalam mengekpor produk yang telah dibuat, banyaknya pengangguran diberbagai daerah, meningkatnya kriminalitas, serta meningkatnya jumlah angka kemiskinan di Indonesia yang mengakibatkan pandemi COVID-19 menyebar.

Tidak hanya itu, menyusutnya kondisi sosial-ekonomi masyarakat berakibat pada bidang keamanan yaitu meningkatnya kriminalitas di Indonesia selama pandemi COVID-19 sedang berlangsung yang mengancam keselamatan dan keamanan warga masyarakat. Dengan kewajiban menjalankan protokol kesehatan dengan melaksanakan kebijakan lockdwon seperti Pembatasan Sosial Berskala Besar (PSBB),menjaga jarak (social distancing), rajin mencuci tangan menggunakan sabun,menerapkan pola hidup sehat, serta mengenakan masker sampai pelaksanaan new normal pada saat ini. Warga masyarakat tetap berantisipasi penularan COVID-19 dengan menutup tempat keramaian, membatasi untuk pergi hajatan,dan menutup semua tempat agar masyarakat yang lain tidak bisa keluar masuk kampung seenaknya sendiri. Kesertaan warga masyarakat untuk bahu-membahu dalam menghadapi wabah ini sangat bagus sekali serta membangkitkan semangat para warga dalam memperkecil penyebarannya.

Kepala Negara Joko Widodo menerangkan, kesertaan warga masyarakat menjadi kunci terpenting untuk penanggulangan penyebaran wabah virus corona ataupun COVID-19. Salah satu himbauan pemisahan sosial menuntut pemahaman masyarakat untuk menjauhi gerombolan, semacam melindungi jarak dari orang lain minimal satu meter, mengurangi berjalan ke zona yang dilarang pemerintah (mal, biokop, stadion, sekolah, tepat ibadah, bangunan rezim, dsb), menggunakan penutup hidung dan mulut, mengurangi bersinggungan serta serupanya. Aturan pemisahan sosial untuk memaksa warga masyarakat untuk berlatih dari rumah, ibadah harus dirumah, serta bertugas hanya di rumah. Masyarakat juga harus mengikuti anjuran dari pemerintah untuk tetap mematuhi protokol kesehatan dan memiliki kesadaran diri secara mandiri agar penyebaran COVID-19 bisa hilang dari muka bumi. Selain itu, jangan lupa untuk berolahraga setiap hari atau seminngu dua kali agar tubuh tetap sehat dan bugar supaya bisa terhindar dari virus yang datang. Sementara itu, kebijakan lockdowon juga diterapkan di Negara Tetangga yaitu Negara Malaysia sebab banyak TKI (Tenaga Kerja Indonesia) ilegal yang lewat "jalan tikus". Mengingat penyebaran COVID-19 yang terus meningkat serta dampak yang ditimbulkan maka Presiden Joko Widodo mengeluarkan Keputusan Presiden (Keppres) mengenai penetapan musibah penyebaran COVID-19 di Indonesia sebagai bagian bencana nasional. Pemerintah telah melakukan beberapa cara untuk menanggulangi pandemi Corona dengan membentuk Satuan-Satuan Gugus Tugas dalam Penindakan pandemi COVID-19 dengan beberapa menteri-menteri atau lembaga yang bersangkutan Kemhan serta Tentara Nasional Indonesia merupakan kedua lembaga yang ikut serta berperan aktif untuk mengupayakan menanggulangi pandemi ini yang menyebar di seluruh Indonesia.Tetapi, 
keterkaitan lembaga pertahanan dalam menanggulangi pandemi COVID-19 serta pada pelaksanaan fase new normal mengakibatkan terjadinya fakta dan opini di masyarakat. Beberapa pihak menanggapi sebagai sesuatu yang normal tetapi sebagian pihak lainnya mengkritik hal yang penting tentang keterkaitan lembaga pertahanan. Pihak yang menganggap fakta mengkritik tidak adanya Keputusan Kepolitikan Negara yang seharusnya dibuat sebelum pengarahan dilaksanakan. Selain itu, timbulnya kekhawatiran bahwa masuknya militer memicu suasana yang menegangkan didalam masyarakat sehingga terjadinya Pelanggaran hak dan kewajiban ketika terjadi Penyalahgunaan Kekuasaan. Pada hakikatnya keterkaitan Tentara Nasional Indonesia dan Kemhan telah sesuai dengan ketentuanketentuan yang telah ditetapkan Nomor 4 Tahun 2019 serta UU Tentara Nasional Indonesia (TNI) Nomor 34 Tahun 2004. Dari berbagai kritik diatas, Tentara Nasional Indonesia (TNI) dan Kementerian Pertahanan (Kemhan) sudah melaksanakan beberapa langkah yang sangat strategis untuk menanggulangi wabah COVID-19 yang sedang berlangsung ini.

\section{METODE}

Data riset ini memakai tata cara kualitatif yaitu memakai metode pendekatan atau pengumpulan informasi dari orang ke orang secara langsung dalam cara alamiah. Tata cara ini dibuat untuk mendapatkan informasi secara langsung dari warga masyarakat tentang bagaimana mencegah dan menanggulangi dampak pandemi COVID-19 yang merebak di Indonesia. Dengan metode ini, peneliti lebih mudah untuk mendapatkan informasi secara akurat dan terperinci sebab peneliti turun langsung kelapangan untuk mengadakan observasi (pengamatan) dan wawancara langsung kepada warga masyakarat tentang penanggulangan COVID19 pada saat ini. Jadi, proses penelitian ini dibuat dengan mengumpulan informasi, menampung aspirasi dari berbagai warga masyarakat serta membuat laporan hasil observasi yang telah dilakukan sebelumnya. Peneliti juga menjelaskan bagaimana kedudukan pemerintah dan warga masyarakat dalam usahanya untuk menghindari COVID19 serta apa yang bisa dilakukan untuk tetap tinggal rumah. Dampak yang ditimbulkan dari virus tersebut sangat besar sehingga masyarakat harus mempunyai semangat juang yang tinggi supaya Virus Corona dapat hilang dari muka bumi.

\section{Teori Kedudukan}

Kedudukan merupakan serangkaian perilaku yang di inginkan seseorang untuk mengubah seseorang kearah yang lebih baik dari pada sebelumnya. Kedudukan dilandasi dengan harapan atau keinginan untuk mendapatkan sesuatu yang diberikan dengan baik secara resmi ataupun tidak resmi. Kedudukan mencakup tiga hal yang perlu diperhatikan antara lain sebagai berikut :

a. Adanya serangkaian peraturan yang berlaku dalam masyarakat untuk membimbing seseorang menjadi lebih baik dalam bermasyarakat.

b. Keikutsertaan masyarakat dalam berorganasisasi.

c. Mempunyai sikap dan tingkah laku yang baik dalam kepemimpinan bermasyarakat dan bernegara.

Kedudukan dianggap sebagai bukti tingkah laku, sikap dan keinginan yang mau dicapai seseorang dalam mengubah perilaku yang kurang baik menjadi lebih baik supaya seseorang dapat bermanfaat dan berguna dimasa yang akan datang nantinya. Kedudukan juga sebagai tempat untuk masyarakat dalam menentukan jati dirinya.

\section{Rancangan Pertahanan Negara}

Dalam UU No.12 Tahun 2002 Pertahanan Negara yaitu segala cara untuk mempertahankan Negara Kesatuan Republik Indonesia (NKRI) serta keamanan segenap bangsa dan negara dari berbagai ancaman terhadap kesatuan bangsa yang bernegara. Pertahanan Negara berperan aktif dalam menciptakan dan mewujudkan kedaulatan negara sebagai suatu kesatuan. Pertahanan Negara diadakan oleh pemerintah untuk membangun dan membina keahlian untuk mencegah bangsa dan negara dalam mengatasi berbagai macam ancaman yang 
berasal dari luar. Sistem pertahanan negara merupakan sistem pertahanan yang sifatnya semesta yang mengaitkan segala masyarakat negara, daerah, serta sumber energi nasional yang lainnya, dan dipersiapkan secara matang oleh pemerintah serta diselenggarakan secara total, terpadu, terencana, terarah, serta bersinambung untuk menegakkan kedaulatan negara, keutuhan daerah, serta keselamatan dan keamanan segenap bangsa dan negara dari seluruh ancaman yang berasal dari luar. Unsur Pertahanan meliputi komponen pokok, komponen cadangan, dan komponen pendukung.

Komponen Pokok merupakan komponen yang anggotanya Tentara Nasional Indonesia (TNI) yang mengemban tugas utamanya untuk mempertahanan suatu bangsa dan negara, melindungi masyarakat dari berbagai macam ancaman. Komponen Cadangan merupakan sumber energi potensial yang dipergunakan untuk menguatkan komponen sebelumnya dan memberikan ketahanan yang sangat baik dalam penanganan COVID-19. Sedangkan Komponen Pendukung merupakan sumber energi yang digunakan Tentara Nasional Indonesia (TNI) untuk memperkuat pertahanan dalam menghadapi ancaman yang datang untuk melindungi warga masyarakat yang tertimpa musibah baik alam ataupun non-alam. Pemerintah juga memfasilitasi pelayanan kesehatan kepada para tenaga kedokteran supaya bisa menjalankan tugasnya secara optimal.

\section{Rancangan Penanggulangan Pandemi COVID-19}

\footnotetext{
Menurut pandangan Organisasi Kesehatan terdapat lima cara untuk menanggulangi pandemi virus corona. Pertama, mengantisipasi datangnya virus yang akan menyerang tubuh manusia dengan memfasilitasi keamanan untuk menjaga kekebalan tubuh dari berbagai penyakit. Kedua, mendeteksi hewan apakah didalam tubuh terdapat virus yang bisa menyerang manusia atau tidak sebab manusia sangat rentan terhadap penyakit yang bisa masuk ke dalam tubuh manusia. Ketiga, mengusahakan penyakit supaya tidak masuk ke dalam tubuh manusia dengan cara melakukan pola hidup
}

sehat secara teratur. Keempat, melakukan pengecekan secara berkala selama pandemi COVID-19 yang belum mereda atau menyusut. Kelima, mengetahui efek yang ditimbulkan akibat penyebaran COVID-19 di Indonesia. Selain itu, World Health Organization (WHO) juga mempunyai langkah-langkah yang sangat efisien dan efektif untuk menanggulangi wabah virus corona ini.

Pertama, mengkoordinasi dengan lembaga satu dengan lembaga yang lainnya untuk mengestimasi dampak yang akan terjadi. Dengan adanya wabah seperti ini pemerintah menyediakan perlengkapan yang menunjang suatu organisasi untuk membantu warga masyarakat dalam beraktivitas dan bertanggung jawab atas kebutuhan yang kurang memadai. Pemerintah juga memberikan fasilitas yang sangat cukup dalam menunjang perekonomian masyarakat.

Kedua, membuat data kesehatan yang berisikan seseorang yang terdampak wabah corona serta membuat kebijakan pengawasan wabah penyakit yang sudah diuji cobakan sebelumnya. Supaya dapat memperkecil penyebaran virus dan bisa segera diatasi. Dalam hal ini, pemerintah juga menguji cobakan vaksin yang telah dibuat di daerah Bandung tetapi banyak masyarakat yang telah mencoba vaksin tersebut dan hasilnya tidak memuaskan.

Ketiga, penanggulangan pandemi COVID-19 secara singkat dan cepat untuk dipertanggung jawabkan dalam membuat kebijakan secara cermat dan teliti dalam membasmi wabah penyakit yang akan muncul serta mengelola data para pasien corona secara baik dan benar. Pemerintah juga memberikan pelayanan kesehatan dan perlengkapan yang efesien dan terpadu kepada para pasien COVID-19.

Keempat, melaksanakan pengamatan di berbagai bidang kesehatan dalam rangka mengurangi penularan COVID-19 yang berdampak pada kematian serta berakibat sangat buruk dalam bidang kesehatan ataupun bidang-bidang yang lainnya. Pemerintah melakukan evakuasi di sejumlah titik rawan penyakit dan membantu para pasien dalam melaksanakan aktivitasnya. 


\section{HASIL DAN PEMBAHASAN}

Virus Corona merupakan virus yang menimbulkan peradangan saluran pernapasan. Virus ini banyak memakan korban jiwa sampai meninggal dunia,karena virus ini menyebar melalui udara sehingga masyarakat harus lebih hati-hati dan teliti dalam menjaga kesehatan tubuh yang sangat rentan terhadap penyakit. Butuh adanya partisipasi dan kesadaran masyarakat bersama-sama pemerintah untuk menangani penyebaran COVID-19 yang sudah menyebar diseluruh dunia. Selain itu juga, penting untuk masyarakat dan pemerintah untuk lebih mendekatkan diri kepada Tuhan Yang Maha Esa karena wabah seperti ini merupakan ujian bagi seluruh Indonesia untuk lebih mendekatkan diri kepada sang Maha Pencipta. Sekarang semua warga masyarakat di dunia benar-benar menjaga kebersihan diri secara mandiri dan berusaha memusnahkan virus dengan penyemprotan disinfektan secara rutin di lingkungan tempat tinggal. Tidak hanya itu, keterkaitan Kementerian pertahanan (Kemhan) bersama-sama dengan Tentara Nasional Indonesia (TNI) dalam membantu mengatasi penyebaran COVID-19 juga sangat penting. Sebab lembaga pertahanan dapat membantu dan mengatasi permasalahan yang terjadi seperti menangani permasalahan krisis kesehatan global akibat pandemi COVID-19. Selain itu, Panglima Tentara Nasional Indonesia (TNI) menggerakkan semua personil, fasilitias sarana dan prasana dalam upaya untuk menghindari terjadinya bencana atau musibah yang terjadi dengan membentuk kedaruratan kesehatan masyarakat. Serta memberikan penanggulangan secara taktis kepada warga masyarakat yang tertimpa bencana. Presiden Joko Widodo bersama Menteri Pertahanan memberikan pengarahan serta kerja sama untuk menghindari, mengetahui, serta dapat merespon dengan baik apa yang seharusnya dilakukan untuk memperkecil penyebaran virus yang sedang marak-maraknya di Indonesia. Pemerintah berharap agar virus corona ini bisa cepat musnah dan keadaan kembali seperti biasa.

\section{Kedudukan Tentara Nasional Indonesia (TNI)}

\section{a. Bidang Kesehatan}

Kesehatan merupakan upaya untuk menanggulangi gangguan dari penyakit yang muncul baik yang memerlukan pemeriksaan ataupun tidak, tetapi kesehatan sangat penting bagi manusia karena kesehatan mahal harganya dan tidak bisa dibeli dengan apapun. Untuk itu, kita harus menjaga dan melindungi kesehatan pada organ tubuh kita dengan baik untuk bisa terhindar dari virus yang berbahaya. Dibidang kesehatan, Tentara Nasional Indonesia sudah melaksanakan penganggaran sebesar Rp 190,8 Milyar untuk membantu penanggulangan pandemi COVID19. Keikutsertaan Markas Besar Tentara Nasional Indonesia (Mabes TNI) sangat penting sekali dalam membantu para warga masyarakat yang kebutuhannya sangat terjangkau dan membantu para dokter dalam memberikan pelayanan yang terbaik kepada para pasien yang terjangkit COVID-19. Berdasarkan penganggaran tersebut, sebanyak Rp 20,7 Milyar digunakan untuk menyediakan perlengkapan laboratorium Polymerase Chain Reaction (PCR) khusus untuk yang terjangkit virus corona. Selanjutnya, penganggaran Tentara Nasional Indonesia Angkatan Darat (TNI-AD) sebanyak Rp 25,3 Milyar dipergunakan untuk membeli alat pelindung diri (APD) dan alat untuk menguji virus seperti swab test. Tentara Nasional Indonesia Angkatan Laut (TNI-AL) memberikan anggaran sebanyak Rp 60,4 Milyar untuk memfasilitasi alat-alat yang dibutuhkan untuk para pasien corona yaitu dengan menyediakan hand sanitizer, masker, vitamin untuk menjaga imunitas tubuh, dan ruang untuk mengisolasikan diri. Sebaliknya, Tentara Nasional Indonesia Angkatan Udara (TNI- AU) memberikan anggaran sebanyak Rp 65,2 Milyar untuk para tenaga kedokteran dalam merawat pasien yang terdampak COVID-19 dan untuk kompensasi khusus tenaga kesehatan di sebagian rumah sakit.Tentara Nasional Indonesia (TNI) ikut serta dalam membantu memfasilitasi sarana prasarana kesehatan yaitu dengan menyediakan Rumah Sakit khusus untuk para pasein yang positif COVID-19. Tentara 
Nasional Indonesia (TNI) bersama dengan Kementerian Pertahanan (Kemhan) menyediakan perlengkapan kedokteran serta mendirikan tenda dengan tujuan untuk penindakan terhadap orang yang terjangkit COVID-19. Tenda tersebut berguna untuk mempercepat tindakan kepada seseorang yang terduga terkena virus COVID-19 yang sebelum dibawa ke rumah sakit wisma atlet untuk pasien corona. Setelah itu, pemerintah memberikan sumbangan sebanyak $\mathrm{Rp}$ 2,5 triliun untuk menggerakan semua pasukan Tentara Nasional Indonesia (TNI) dalam penindakan COVID-19 yang sedang menyerang warga masyarakat Indonesia. Sumbangan tersebut digunakan untuk fasilitas sarana prasarana pelayanan kesehatan yang terdapat diseluruh wilayah Indonesia. Hal-hal seperti ini dilakukan supaya fasilitas yang diberikan oleh TNI dapat dipergunakan untuk penindakan secara cepat dalam menghadapi pandemi COVID-19. Selain itu, Tentara Nasional Indonesia Angkatan Darat (TNIAD) menyediakan perlengkapan laboratorium Polymerase Chain Reaction (PCR) yang digunakan pada setiap Rumah Sakit khusus untuk para pasien corona. Dengan adanya bantuan tersebut, persoalan yang dihadapi bisa teratasi satu persatu khususnya pada tenaga kesehatan karena banyaknya kekurangan tenaga kesehatan dalam menangani COVID-19 yang semakin hari semakin menambah banyak. Akhirnya pemerintah memberikan dana APBN (Anggaran Pendapatan Belanja Negara) untuk bidang kesehatan karena pengabdiannya kepada para pasien untuk merawatnya sampai sembuh sehingga para tenaga kedokteran rela meninggalkan sanak saudara demi menyelamatkan dunia dari paparan virus corona.

Dari sisi Sumber Daya Manusia (SDM) dalam bidang kesehatan Tentara Nasional Indonesia (TNI) telah mempersiapkan seluruh jiwa raganya dalam menjaga para pasien COVID19 yang telah dirawat di Rumah Sakit khusus yaitu Rumah Sakit Darurat Wisma Altet Kemayoran, Jakarta Pusat. Dalam penanganannya tenaga kesehatan menjadi sangat penting karena keterkaitan mereka semua menjadi penunjang kesehatan dalam mengupayakan keselamatan segenap bangsa dan negara. Pengadaan SDM Kesehatan dengan melakukan penempatan tenaga kesehatan untuk mencapai keadilan dalam pembangunan. Dari sisi Penyediaan, Tentara Nasional Indonesia (TNI) mengirimkan APD diberbagai wilayah Indonesia yang bertujuan untuk menanggulangi dampak pandemi COVID-19. Pengiriman APD tersebut dilakukan ke 34 Provinsi di Indonesia yang berada pada zona rawan penyakit atau susah djangkau dan Tentara Nasional Indonesia (TNI) juga ikut serta menjaga ruang isolasi secara ketat untuk menekan penyebaran COVID-19, serta melaksanakan dalam pembuatan vaksin dan obat-obatan yang dapat mencegah atau memperkecil COVID-19 yang di buat didalam Laboratorium Kesehatan. Dalam pembuatan vaksin diberbagai negara belum ada yang berhasil sehingga sampai saat ini,belum ada obat yang bisa mencegah datangnya virus baru. Mereka yang terjangkit virus mendapatkan perawatan yang intensif untuk menekan gejala serta yang penyakitnya sudah serius harus segara dibawa ke Rumah Sakit khusus para pasien COVID-19. Tenaga Kesehatan juga bekerja semaksimal mungkin dalam menyembuhkan para pasien yang terjangkit virus corona sehingga tenaga kesehatan sangat berperan aktif dalam menanggulangi dampak pandemi COVID-19. Pada masa pandemi pelayanan kesehatan membutuhkan perhatian yang serius karena kesehatan para medis juga sangat penting. Tenaga kerja juga mendapatkan alat perlindungan diri dengan kualitas yang sangat bagus supaya pada saat digunakan bisa nyaman dan optimal dalam menjalankan tugasnya.

\section{b. Bidang Keamanan}

Keamanan merupakan keadaan untuk melindungi diri dari suatu yang buruk yang dianggap tidak baik dan tidak boleh dilakukan. Keamanan juga melindungi warga masyarakat dari hal-hal yang tidak di inginkan. Dibidang keamanan, Tentara Nasional Indonesia (TNI) harus mempunyai solidaritas yang tinggi dalam menekan laju penyebarana COVID-19. Dalam rangka menegakkan serta mengawasi kedisiplinan 
Tentara Nasional Indonesia (TNI) melaksanakan jaga malam ditempat-tempat umum yang dapat menimbulkan terjangkitnya virus serta melakukan pengawasan terhadap kedatangan TKI ilegal yang memasuki wilayah Indonesia. Kedatangan TKI ilegal dapat meresahkan warga masyarakat karena sebelum datang di Indonesia orang tersebut sudah terpapar virus yang tidak sadar sudah masuk ke dalam tubuh orang itu. Sehingga sebelum pulang ke Indonesia diwajibkan untuk rapid test dan test swab supaya bisa tau bahwa orang tersebut positif COVID-19 atau tidak. Setelah hasil sudah menunjukkan bahwa negatif COVID-19, akhirnya bisa pulang ke Indonesia. Sesampainya di Indonesia seseorang yang baru saja tiba dari luar negeri harus isolasi mandiri selama 14 hari, melampirkan surat keterangan sehat dari dokter,dan rapid test kembali supaya benarbenar aman dari terpaparnya virus corona. Para tenaga kerja kembali ke kampung halamannya karena dipecat oleh majikannya sebab situasi perekonomian yang sangat sulit dan tidak bisa menjangkau kehidupannya mereka di negara tetangga.

Berikutnya,sebagai langkah preventif, Tentara Nasional Indonesia (TNI) melakukan persiapan dalam mencegah hal buruk yang akan terjadi dan meminimalisir terjadinya gejolak sosial dan aksi yang anarkis. Oleh karena itu, untuk meredam gejolak sosial maka warga masyarakat harus menjaga keamanan dan ketertiban dalam bertindak agar tidak terjadi kekisruhan antar masyarakat yang lain. TNI juga membantu memberikan pengarahan dalam tata cara pemakaian masker serta pelaksanaan physical distancing ditempat keramaian seperti halte, terminal, dan pusat berbelanja. Dalam memasuki fase new normal Tentara Nasional Indonesia (TNI) turun langsung untuk mengamankan beberapa tempat umum untuk sementara waktu meliputi pasar,terminal,stasiun,dan halte. Setelah kondisi sudah memungkinkan tempattempat tersebut dibuka kembali seperti semula agar para warga masyarakat dapat beraktivitas kembali tetapi harus tetap mematuhi protokol kesehatan yang telah dianjurkan oleh pemerintah setempat. Keterkaitan TNI dan POLRI dalam menertibkan masyarakat untuk mematuhi protokol kesehatan sangatlah penting dan produktif supaya bisa mendapatkan kenyaman terhindarnya dari penularan COVID-19. Pemerintah juga harus memberikan pelayanan yang terbaik untuk melindungi masyarakat dari tindakan yang tidak baik dan senantiasa menjadi penanggung jawab yang baik dan bijaksana untuk mengayomi para warga masyarakat dari berbagai ancaman.

\section{c. Bidang Sosial-Ekonomi}

Sosial-Ekonomi

merupakan

kedudukan para warga masyarakat dalam aktivitasnya untuk mendapatkan penghasilan dan pendidikan yang memadai untuk mencapai suatu keberhasilan. Akibat pandemi COVID-19 negara kita mengalam krisis keuangan yang menghambat bahkan dapat menghancurkan segala perekonomian di masyarakat. Selain itu, pemerintah juga memberikan bantuan UMKM untuk para pedagang diluar sana sebesar Rp 2,4 juta untuk modal supaya bisa membangkitkan penjualan yang selama pandemi penghasilan yang didapat tidak mencukupi. Bukan hanya itu, pemerintah memberikan bantuan subsidi gaji kepada para karyawan pabrik sebesar Rp 1,2 juta untuk menunjang perekonomannya. Bantuan tersebut sangat berguna dan bermanfaat untuk para warga masyarakat yang kesusahan dalam mendapatkan penghasilan selama pandemi dan banyak pekerja yang diberhentikan. Selama pandemi sulit sekali dalam mencari pekerjaan akhirnya banyak juga penjahat yang merajalela seperti pencuri, perampok, dan tindakan kriminal yang lainnya. Hal tersebut sangat meresahkan warga masyarakat sehingga masyarakat mengadakan penjagaan malam untuk mengatasi pencurian di dalam kampungnya. Selanjutnya, Tentara Nasional Indonesia (TNI) memberikan bantuan sosial seperti sembako untuk masyarakat yang memerlukan. Program ini diperuntukkan untuk masyarakat yang terdampak COVID-19. Bantuan tersebut diberikan setiap satu bulan sekali dan sangat membantu untuk kebutuhan para warga masyarakat. TNI juga memberikan bantuan uang dan sembako untuk masyarakat yang kurang mampu supaya bisa melanjutkan 
kehidupannya. Berkat TNI, Polri, dan pemerintah dalam membantu perekonomian warga masyarakat sehingga para warga bisa terbantu atas semua yang telah diberikan. Polri juga memberikan donasi masker untuk masyarakat yang keluar rumah tanpa menggunakan masker dan apabila dilanggar terus menerus akan berakibat pelanggar kecil dan bisa mendapatkan denda sebesar Rp 250.000.

\section{Kedudukan Kementerian Pertahanan (Kemhan)}

Kemhan menyediakan disinfektan di area tempat umum dan menyediakan kebutuhan dalam protokol kesehatan. Kemhan juga berencana mendirikan farmasi untuk pertahanan kesehatan secara mandiri di masa yang akan datang karena mereka menyadari bahwa COVID-19 mempunyai akibat yang sangat besar kepada kehidupan warga masyarakat. Oleh karena itu, Kemhan mengestimasi dampak akibat wabah penyakit dengan berkoordinasi bersama Kementerian terkait dalam menanggulangi penyebaran COVID-19. Disamping itu, Kemhan juga memberikan alat perlengkapan kesehatan seperti sarung tangan, alat pelindung diri (APD), vitamin, dan ventilator dalam menunjang peralatan kedokteran yang kurang memadai. Keberadaan Kemhan sangat penting dalam mengatasi penyebaran COVID-19 sehingga kemhan juga berusaha semaksimal mungkin dalam membantu warga masyarakat yang mengalami kesulitan bahan pangan atau kondisi yang lainnya. Selain itu, Kemhan bekerja sama dengan perusahaan lain yaitu sebagai berikut :

\section{a). Kerja sama Kemhan dengan perusahaan-perusahaan Swasta}

Perusahaan Swasta merupakan perusahaan yang bergerak di bidang swasta untuk memperjual-belikan produk di luar negeri bahkan di Indonesia sekaligus. Di perusahaan ini tempat para warga masyarakat bekerja untuk mendapatkan penghasilan dalam mencukupi kebutuhannya. Sebagian besar perusahaan-perusahaan yang terdapat di Indonesia dipegang atau dikendalikan oleh China. Sekarang sawah atau lahan banyak dibangun untuk mendirikan suatu perusahaan sehingga beras semakin naik harganya. Untuk itu, kita sebagai anak muda harus pintar bahkan sampai membuka lapangan kerja sendiri tanpa ikut kerja sama dengan perusahaan lain. Sementara ini, Kemhan sangat berperan aktif dalam membantu para tenaga kesehatan dan para pasien COVID-19. Kemhan banyak mendapatkan bantuan alat perlengkapan dari China berupa sarung tangan, penutup kepala, masker, hand sanitizer, dan sepatu pelindung. Tidak hanya itu, kemhan juga mendistribusikan paket makanan untuk para relawan COVID-19 yang senatiasa merawat dan menjaga para pasien sampai benar-benar sembuh. Berikutnya, Kemhan dan PT Japfa Comfeed memberikan donasi kepada para tenaga kedokteran dalam menanggani pasien COVID-19. Program ini diadakan dalam rangka untuk mempersatukan bangsa dan negara dalam melawan virus yang sedang menyebar ini. Kemhan juga memberikan 10.000 makanan untuk para pasien yang terdapat di Rumah Sakit khusus COVID-19 setiap harinya tanpa pamrih.

\section{b). Kerja sama Kemhan dan Badan Usaha Milik Negara (BUMN) di bidang Pertahanan}

BUMN merupakan badan usaha yang segala sesuatunya dipegang oleh pemerintah. Dalam hal ini, Kemhan juga bekerja sama dengan BUMN terkait untuk mengatasi penyebaran COVID-19. Jumlah pasien corona semakin hari semakin bertambah banyak. Suasana tersebut sangat mendesak kemhan dalam memberikan peralatan yang sangat cukup dalam memberikan pertolongan kepada pasien corona. Beberapa BUMN juga memproduksi alat-alat kesehatan yang dibutuhkan seperti oksigen, ventilator, masker, hand sanitizer, ruang isolasi, dan vitamin untuk menambah stamina para pasien. BUMN dalam bidang Pertahanan telah membuat Peralatan Mekanik untuk menghasilkan udara yang telah lulus uji dalam membantu para pasien yang susah untuk bernafas. Kedudukan kedua BUMN tersebut sangat membantu sekali dalam menghadapi pasien yang sakit parah. Oleh karena itu, Kemhan beserta BUMN terkait 
sama-sama bekerja sama dalam menumpas penyebaran COVID-19 yang sedang melanda Indonesia. Secara garis besar, pertahanan merupakan suatu badan untuk melindungi diri dari bahaya resiko yang mengancam keselamatan dan keamanan warga masyarakat dalam mempertahankan Kesatuan dan Persatuan Bangsa Indonesia. Dalam keadaan pandemi COVID-19 seperti saat ini, beberapa BUMN menggunakan keahlian dalam sumber daya potensial seperti mesin-mesin untuk ikut serta dalam memproduksi perlengkapan kedokteran untuk membantu para tenaga dokter dalam menanggulangi COVID-19 yang sedang berlangsung.

\section{c). Kerja Sama Kementerian Pertahanan dengan Negara Asing}

Indonesia telah bekerja sama secara bilateral atau regional. Bilateral merupakan kerja sama dengan dua orang saja sedangkan Regional merupakan kerja sama yang dilakukan di kawasan tertentu di negaranegara dalam suatu wilayah. Dalam kerja sama pada tingkat regional, Kemhan mengupayakan membangun kerja sama dengan baik dalam hal penguatan penindakan pandemi COVID-19. Melalui ASEAN Defence Senior Officials Meeting Working Group (ADSOM-WG) yang berlangsung pada 10 Mei 2020, Direktur Kerja sama Internasional Pertahanan menegaskan bahwa ASEAN harus mengikuti kesepakatan para Menteri khususnya dalam penindakan pandemi COVID-19 untuk bertukar pikiran dalam memberantas Virus Corona yang menyebar di belahan dunia. Di tengah-tengah krisis kesehatan global ini, pasukan pertahanan di nilai baik dalam menangani seluruh permasalahanpermasalahan yang terjadi di lapangan. Tentara Nasional Indonesia (TNI) telah melakukan operasi dalam penindakan pandemi COVID-19 yaitu Pertama, menyediakan sarana prasarana pelayanan kesehatan apakah sudah mencukupi atau belum sehingga bila digunakan suatu saat tidak kehabisan stok peralatan atau obatobatan yang dibutuhkan untuk para pasien dan tenaga medis lainnya. Tenaga kedokteran selalu bersiaga untuk membasmi virus ini sehingga tenaga medis mengadakan rapid test diluar Rumah Sakit dengan menggunakan Driver Thru. Jadi orang yang ingin rapid test tidak harus keluar dari mobil tetapi tenaga medis yang menghampiri para pasien yang ingin rapid test dan hasilnya satu hari bisa jadi dengan ketentuan biaya yang dikeluarkan juga banyak. Hasil tersebut akan dikirim melalui email masing-masing yang rapid test selama $1 \times 24$ jam.

Kedua, melakukan pengamanan di sejumlah titik yang rawan penyakit. Serta mengamankan objek tempat keramaian seperti pasar, mall, tempat karaoke, bioskop, dan masih banyak lagi. Semua diamankan dan dibatasi untuk berkunjung dalam tempattempat tersebut agar dapat memperkecil penyebaran COVID-19. Untuk itu, para TNI dan Polri melakukan patroli di perbatasan wilayah Indonesia-Malaysia.

Ketiga, mengambilan bantuan dari negara lain yaitu China karena negara tersebut banyak memberikan donasi dan peralatan untuk melindungi ketertiban masyarakat untuk mematuhi protokol kesehatan pada masa PSBB. Warga masyarakat harus tetap waspada sebab kasus positif COVID-19 semakin bertambah dan semakin meningkat. Terjadinya wabah corona ini juga bisa membuat semua warga mayarakat tidak bisa mendapatkan kebebasan. Disaat seperti ini, maka kita harus memiliki solidaritas yang tinggi untuk membantu pemerintah dalam usahanya untuk membasmi virus ini yaitu dengan mematuhi peraturan yang telah ditetapkan oleh pemerintah. Untuk itu, Tentara Nasional Indonesia (TNI) dan Kementerian Pertahanan (Kemhan) sangat berperan penting dalam menekan laju penyebaran COVID-19 yang ada di Indonesia. Gugus Tugas COVID-19, Letnan Jenderal Doni sebagai Kepala Tubuh dalam menanggulangi wabah corona ini sangatlah tepat karena penanganan yang sangat bagus dan tepat bisa memperkecil penyebarannya. Tentara Nasional Indonesia (TNI) juga mempersiapkan Rumah Sakit khusus untuk pasien COVID-19, Pasien dalam Pengawasan (PDP), serta Orang Dalam Pengawasan (ODP).

Indonesia telah melalui fase pada tahap 
mendeteksi pada hewan yang berbahaya karena dapat menulari virus melalui air liurnya. Tentara Nasional Indonesia (TNI) dan Kemhan juga memberikan fasilitas penyaluran bantuan perlengkapan rapid test serta perlengkapan kesehatan dari negara lain agar cepat di distribusikan ke semua wilayah di Indonesia. Penghambatan penyakit yang dilakukan pada masa ini mungkin karena telah terjalin penyebaran keberbagai daerah dan pemerintah sudah melakukan PSBB di daerah-daerah yang rawan. Tentara Nasional Indonesia (TNI) dan Kemhan juga turut ikut serta dalam melawan pandemi COVID-19 dengan cara menggerakkan pasukan yang bertugas melindungi dan menertibkan warga masyarakat dalam menaati anjuran dari pemerintah dalam menjaga kesehatan tubuh agar terhindar dari COVID-19 selama berlakunya PSBB serta melakukan evakuasi di sepanjang jalan terutama di jalan yang dilarang untuk mengawasi jalur masuk penduduk yang berpindah-pindah tempat serta melaksanakan penyaringan kesehatan kepada orang-orang yang mau masuk dan keluar dari berbagai wilayah atau daerah. Pada saat ini, Indonesia telah memasuki pada tahap fase keadaan yang normal karena pemerintah telah membuat zona sesuai dengan tingkatan efek wabah corona di masing-masing daerah setelah itu menetapkan aturan pembatasan di daerah yang masuk kedalam zona yang tingkat wilayahnya beresiko tinggi, zona tingkat wilayahnya beresiko sedang serta zona yang beresiko rendah dan mendapat kebebasan untuk daerah yang masuk dalam zona yang belum terdampak COVID-19. Tidak hanya itu, dampak yang ditimbulkan bidang sosialekonomi akibat pandemi COVID-19 membuat tingginya angka kriminalitas (tingkat kejahatan) semakin bertambah, sehingga kedatangan Tentara Nasional Indonesia (TNI) serta Polisi dinilai baik untuk meningkatkan rasa keamanan dan kenyaman di masyarakat. World Health Organization (WHO) juga memberikan langkah-langkah koordinasi secara efisien berupa Pertama, Tentara Nasional Indonesia (TNI) dan Kemhan telah melakukan metode koordinasi dengan lembaga terpaut seperti Kementerian
Pertahanan, BUMN, perusahaan swasta serta koordinasi dengan lembaga-lembaga pertahanan di negara asing. Kemhan juga memberikan bantuan untuk para bidangbidang penting dalam menanggulangi pandemi COVID-19. TNI juga sudah menyiapkan pelayanan di bidang kesehatan dalam mengestimasi penyebaran virus yang akan datang. Sumber daya manusia juga telah memberikan efek yang baik terhadap penanganan virus ini karena sumber daya manusia merupakan sumber daya yang sangat penting dalam suatu organisasi dan penentuan kesuksesan sebuah organisasi atau perusahaan.

Kedua, mencari data informasi akibat kebijakan yang telah dilakukan sebelumnya. TNI secara bertahap menyampaikan peraturan tersebut secara berkala menggunakan media sosial karena lebih mudah dan cepat dalam mengakses informasi yang akan diujikan nantinya. Membuat data-data kesehatan untuk para pasien corona diberbagai wilayah siapa saja yang sudah sembuh ataupun belum agar bisa di evakuasi lagi lebih lanjut agar penindakan pandemi COVID-19 cepat teratasi dengan bijaksana. TNI dan Kemhan juga tidak diam saja mendengar virus ini semakin menjadi dan lembaga pertahanan bergerak cepat melakukan segala cara membuat obat penangkal atau penanganan khusus dalam menekan penyebaran COVID-19.

Ketiga, mengatasi infodemic yaitu penyebaran informasi yang salah atau hoax. Kementerian serta organisasi terkait yang berkewajiban mengatasi infodemic, juga menyampaian peraturan yang telah diuji dicobakan oleh Kemhan serta Tentara Nasional Indonesia (TNI) secara tidak langsung bisa berperan sangat penting untuk meminimalisir infodemic di masyarakat. Penyebaran informasi yang salah juga berpengaruh besar terhadap dampak yang dapat terjadi nantinya. Jadinya, sebisa mungkin kita mendapatkan informasi yang benar dan aktual supaya warga masyarakat dapat percaya dengan infomasi yang kita sampaikan. Infomasi yang salah berdampak negatif untuk masyarakat karena masyarakat sangat mudah untuk terpengaruh 
atau ter provokator oleh orang lain yang menyampaikan informasi tidak sesuai fakta dilapangan. Kemhan tidak ikut serta dalam mengatasi infodemic yang beredar tetapi kemhan dan polri dapat meluruskan permasalahan yang terjadi dilapangan supaya masalah yang salah bisa di atasi dengan baik.

Keempat, melaksanakan penerobosan di berbagai bidang kesehatan dalam rangka mengurangi angka penularan COVID-19, angka pasien yang meninggal dunia serta akibat buruk lainnya yang ditimbulkan. Dengan kedudukan Tentara Nasional Indonesia (TNI) serta Kemhan dalam mengikuti arahan dari gugus tugas secara otomatis penyebaran COVID-19 bisa diminimalisir dengan baik. Dengan adanya langkah-langkah yang strategis dan efektif dalam berkoordinasi sangat membantu dan mempermudah tindakan yang harus dilakukan TNI dan Kemhan dalam mengatasi pandemi saat ini yang menyebar diberbagai wilayah Indonesia. Untuk itu, kita harus menanamkan $3 \mathrm{M}$ yaitu mencuci tangan menggunakan sabun, menjaga jarak minimal satu meter, dan memakai makser bahkan harus bisa menghentikan kegiatan yang mengundang keramaian karena hal tersebut sangat rentan terhadap virus yang dapat menular secara tidak sadar. Pola hidup sehat sangatlah penting dan mudah dilakukan dengan membiasakan mencuci tangan menggunakan sabun, memakai hand sanitizer, dan membersihakan peralatan yang ada di sekitar kita karena benda atau alat-alat yang jarang digunakan bisa menjadi sumber penyakit untuk tubuh kita. Pemerintah serta warga masyarakat harus saling bergotong royong untuk mencegah virus corona yang akan datang. COVID-19 bukan virus yang mainmain tetapi virus yang sangat berbahaya untuk keselamatan manusia.

\section{KESIMPULAN}

Dari penjabaran diatas, kita harus selalu waspada dan hati-hati dengan virus yang menyebar. Jika kita tidak menerapkan pola hidup sehat maka virus akan sangat mudah menempel pada tubuh kita. Upaya yang dilakukan oleh pemerintah sangatlah efektif. Masyarakat ikut serta mematuhi protokol kesehatan yang sudah diatur oleh pemerintah setempat untuk ditaati dan dilaksanakan dengan baik agar tidak mudah untuk penyebarannya. Dengan adanya COVID-19 ini banyak masyarakat yang menghabiskan waktunya di rumah saja seperti belajar dari rumah, bekerja dari rumah, ibadah dari rumah, dan masih banyak lagi. Dalam kondisi yang saat ini masyarakat diwajibkan untuk tetap tinggal dirumah dan jangan meninggalkan rumah kalau tidak dalam keadaan yang sangat mendesak. Padahal pemerintah berharap supaya COVID-19 cepat berakhir dan keadaan kembali seperti sedia kala. Tidak hanya itu, komponen pertahanan telah dikaitkan oleh pemerintah dalam mengatasi pandemi COVID-19 ini. Kedudukan Tentara Nasional Indonesia (TNI) sangat baik sekali dalam penindakan wabah corona seperti di bidang kesehatan, keamanan, serta dalam bidang sosial-ekonomi masyarakat. Selanjutnya, Kemhan juga berperan aktif dalam melakukan kebijakan yang sangat strategis dalam melaksankan kerja sama dengan perusahan swasta, BUMN, hingga pada negara-negara asing di luar sana serta pertahanan nasional juga bisa menguatkan para warga masyarakat akan keresahan yang dihadapi selama pandemi COVID-19. Banyak orang-orang yang tidak mempercayai COVID-19 ada, tetapi virus ini emang benar-benar ada dan sangat mematikan sekali. Kita sebagai warga masyarakat harus selalu tetap waspada apabila keluar dari rumah gunakan masker dan hand sanitizer dimana dan kapan saja karena itu sangat penting untuk dilakukan.

Keterkaitan Tentara Nasional Indonesia (TNI) dalam upaya untuk penindakan COVID-19 mempunyai beberapa kesiapan, keberanian, ketangguhan, dan mental yang kuat untuk dilatih agar selalu senantiasa siap dalam menghadapi keadaan serta situasi dan kondisi yang sangat sulit ini.

Tidak hanya itu, Tentara Nasional Indonesia (TNI) juga mempunyai semangat juang yang tinggi dalam menghadapi pandemi COVID-19 dan melakukan perencanaan secara strategis dalam penindakan wabah ini supaya bisa terlaksana dengan baik dan 
bijaksana. Disamping itu, Kementerian Pertahanan (Kemhan) melaksanakan penganggaran untuk membantu menyediakan kebutuhan bahan pangan dan lainnya dalam penanganan pandemi ini. Pemerintah juga memberikan bantuan subsidi gaji, bantuan non tunai, dan bantuan UMKM untuk para pengusaha yang sekarang pendapatannya sangat menyusut akibat COVID-19. Pemerintah juga banyak mengalami kerugian karena setengah gaji para karyawan swasta dipotong untuk membantu para pasien yang terjangkit COVID-19. Banyak juga karyawan swasta yang di PHK karena perusahaan tidak sanggup untuk mengaji mereka semua karena produksi dari perusahaan tersebut yang tidak stabil dan menurun drastis. Tetapi keadaan dan situasi yang sudah normal para karyawan yang di PHK tadi akan di panggil kembali untuk bekerja seperti semula. Jangan mudah untuk mempercayai informasi yang salah karena dapat merugikan untuk diri sendiri bahkan untuk orang lain yang mendengarnya. Tentara Nasional Indonesia (TNI) bersama dengan Kemhan juga melakukan yang terbaik dan langkah-langkah secara efisien dalam menanggulangi pandemi COVID-19. Semoga pandemi ini bisa berakhir dengan cepat dan keadaan bisa kembali normal seperti biasanya. Melakukan aktivitas tanpa didalam rumah, tetapi kita harus juga menjaga tubuh kita dari penyakit, selalu terapkan hidup sehat, rajin berolahraga, makan makanan yang sehat, selalu menggunakan masker setiap keluar rumah, dan selalu menaati peraturan dari pemerintah. Dengan demikian, Tentara Nasional Indonesia (TNI) dan Kementerian Pertahanan (Kemhan) sangat berperan sangat besar dalam membantu dan mengatasi penyebaran CVID-19 yang melanda di Indonesia. Kita sangat bersyukur mempunyai para relawan dan pahlawan yang tangguh, berani, dan kuat dalam menghadapi apapun untuk membantu para warga masyarakat yang terjangkit virus yang sangat berbahaya bahkan mengancam nyawa manusia.

\section{DAFTAR RUJUKAN}

Handa S. Abidin, S. L. (2013, Januari 16).PENELITIHUKUM.ORG. Dipetik Desember 7, 2020, dari pengertianperusahaan-swasta:

https://penelitihukum.org/tag/pengertianperusahaan-swasta/

https://m.hukumonline.com/berita/baca/lt5 e6326b03aa99/6-hal-yang-perludilakukan-pemerintah-dalampenanganan-covid-19? page $=3$ diakses pada 11 Desember 2020

Ginanjar Adhi, (2020 Februari 8). Penelitian Deskriptif Kualitatif.

Tripven.com.

https://www.tripven.com/penelitiandeskriptif-kualitatif/

Anggraini, Hani. (2020, Juni 16). Keterlibatan Militer Menuju Fase New Normal Tuai Tanda Tanya. Dipetik Desember 7, 2020, dari keterlibatanmiliter-menuju-fase-new-normal-tuaitanda-tanya:

https://www.dw.com/id/keterlibatanmiliter-menuju-fase-new-normal-tuaitanda-tanya/a-53823336

Dzulfaroh, A. N. (2020, Desember 6). Virus Corona di Asia: Indonesia Nomor 4 Kasus Covid-19 Terbanyak. Dipetik Desember 7, 2020, dari virus-corona-diasia--indonesia-nomor-4-kasus-covid-19terbanyak:

https://www.kompas.com/tren/read/2020/ 12/06/080100965/virus-corona-di-asia-indonesia-nomor-4-kasus-covid-19terbanyak?page $=$ all

CNN Indonesia,"Bantuan Medis Corona dari China Tiba di Indonesia" ,28Maret2020,https://www.cnnindonesi a.com/INTERNASIONAL/20200328213252 -113-487878/bantuan-medis-coronadari-china-tiba-di-indonesia, diakses pada 12 November

2020.

Gugus Tugas Percepatan Penanganan COVID19,"PetaSebaran", 5 Juli 2020, https://covid19.go.id/peta- sebaran, diaksespada 6 Desember 2020. 
Hakim, S. (2020, Juni 14). Kesiapan TNIPolri terapkan normal baru ditengah pandemi COVID-19. Dipetik Desember 11, 2020, dari kesiapan-tnipolri-terapkan-normal-baru-ditengahpandemi-covid-19:

https://www.antaranews.com/berita/15 52824/kesiapan-tni-polri-terapkannormal-baru-ditengah-pandemi-covid19

JPNN, "Peran TNI dalam Penerapan PSBB di Tengah Pandemi COVID-19", 15 April 2020 , https://www.jpnn.com/news/perantni-dalam-penerapan-psbb-ditengah-pandemi-covid-19, diaksespada 3Desember 2020.

Dirkersinhan Ditjen Strahan Kemhan Ikuti Pertemuan Virtual ADSOM Working Group. (2020, Mei 12). Dipetik Desember 11, 2020, dari dirkersinhanditjen-strahan-kemhan-ikutipertemuan-virtual-adsom-workinggroup.html.

Wamenhan Dukung Industri Pertahanan Produksi Ventilator. (2020, April 25). Dipetik Desember 11, 2020, dari wamenhan-dukung-industripertahanan-produksi-ventilator.html: https://www.kemhan.go.id/2020/04/25 /wamenhan-dukung-industripertahanan-produksi-ventilator.html

"Kemhan Dukung Tenaga Medis Hadapi COVID-19”, 7 Mei 2020, HTTPS://WWW.KEMHAN.GO.ID/2020/0 5/07/kemhan-dukung-tenaga-medishadapi-COVID-19.HTML, diakses pada 1 Desember 2020.

Sari, H. P. (2020, April 15). TNI Realokasi Anggaran Rp 196,8 Miliar Guna Tangani Covid-19. Dipetik Desember 11, 2020, dari tni-realokasi-anggaranrp-1968-miliar-guna-tangani-covid-19: https://nasional.kompas.com/read/202 0/04/15/12493251/tni-realokasianggaran-rp-1968-miliar-gunatangani-covid-19

admin. (2020, Maret 19). Antisipasi Virus Corona Yonkes 2 Kostrad Siagakan Tenda Isolasi. Dipetik Desember 11, 2020, dari antisipasi-virus-corona-
yonkeS-2-kostrad-siagakan-tendaisolasi.html: https://ni.mil.id/view173699-antisipasi-virus-coronayonkeS-2-kostrad-siagakan-tendaisolasi.html

admin. (2020, April 3). TNI Bantu Distribusikan APD ke Berbagai daerha. Dipetik Desember 11, 2020, dari tni-bantu-distribusikan-apd-keberbagai-daerah.html:

https://tni.mil.id/view-174714-tni-

bantu-distribusikan-apd-ke-berbagaidaerah.html

Portal Berita Resmi. (2020, Desember 9). Dipetik Desember 9, 2020, dari tribratanews.polri:https://tribratanews. polri.go.id/

Wardi, R. (2020, Juni 24). 68 RS TNI AD Dilengkapi Tes PCR. Dipetik Desember 11, 2020, dari kesehatan/648599/68-rs-tni-addilengkapi-tes-pcr: https://www.beritasatu.com/aditya-ldjono/kesehatan/648599/68-rs-tni-addilengkapi-tes-pcr

Questibrilia, B. (2019, Juli 31). Pengertian Sumber Daya Manusia. Dipetik Desember 7, 2020, dari sumber-dayamanusia:https://www.jojonomic.com/b $\log$ /sumber-daya-manusia/

Putri, A. S. (2019, Desember 19). Bentuk Kerja Sama Internasional: Bilateral, Regional, Multilateral. Dipetik Desember 7, 2020, dari bentuk-kerjasama-internasional-bilateral-regionalmultilateral:

https://www.kompas.com/skola/read/2 019/12/19/180000269/bentuk-kerjasama-internasional-bilateral-regionalmultilateral?page $=$ all\#: :text=Kerja $\%$ 20sama\%20regional\%20adalah\%20ke rja,di\%20suatu\%20kawasan\%20atau\% 20wilayah.

Perjuangan TNI Menumpas Pandemi. (2020, Juni 17). Dipetik Desember 11, 2020, dari ragam/komoditas/ekonomi/perjuangan -tni-menumpas-pandemi: https://www.indonesia.go.id/ragam/ko moditas/ekonomi/perjuangan-tnimenumpas-pandemi 
BASKARA, B. (2020, April 18). Rangkaian Peristiwa Pertama Covid-19. Dipetik Desember 11, 2020, dari rangkaianperistiwa-pertama-covid-19/:

https://bebas.kompas.id/baca/riset/202 0/04/18/rangkaian-peristiwa-pertamacovid-19/ 